\title{
Divergent Life History Patterns in the Co- Occurring Intertidal Crabs Panopeus herbstii and Eurypanopeus depressus (Crustacea: Brachyura: Xanthidae)
}

\author{
Jack McDonald* \\ Belle W. Baruch Institute for Marine Biology and Coastal Research, University of South Carolina, Columbia, South Carolina, \\ 29208, USA
}

\begin{abstract}
The xanthid crabs Panopeus herbstii and Eurypanopeus depressus are a co-occurring related species pair that inhabit intertidal oyster reef communities. Panopeus herbstii is larger, faster growing, longer lived and more fecund. Eurypanopeus depressus matures earlier, produces more broods per lifetime and has a shorter generation time. These divergent life history patterns appear related to the different ways in which these 2 crabs utilize food and space in the intertidal zone. $P$. herbstii, which consumes primarily oysters, clams, mussels and barnacles, is prevented by its larger size from entering most of the narrow spaces between living oysters. The narrow spaces are the primary refuge for $E$. depressus which has a less restricted, more omnivorous diet.
\end{abstract}

\section{INTRODUCTION}

Although there is much information concerning the life histories of brachyuran decapods, there has been no organized interpretation of this data in terms of what Stearns (1976) refers to as a 'tactic', i.e. a collection of life history traits exhibited by an organism in a particular ecological situation. Recent interest in population biology and life history theory (Emmel, 1976; Stearns, 1976, 1977, 1980; Hutchinson, 1978) makes it important to begin examining brachyuran life histories from this broader, more organized point of view. First, in keeping with the concept of a 'tactic', life histories should not be seen as isolated bits of information but as overall adaptive patterns which enhance survival in a particular habitat. Second, considering the extent of the literature and the comparatively advanced state of current life history theory, efforts should be made either to reconcile observed patterns with predictive models, or to formulate theories more suitable to the characteristics that define basic brachyuran life history. Third, while understanding that it may never be

- Current address: 4849 S. Indian River Drive, Ft. Pierce, Florida 33450, USA possible to determine the ultimate selective pressures responsible for the evolution of life histories, comparative studies such as those suggested by Stancyk (1979) and performed by Reaka (1979) should be carried out to pinpoint more precisely the proximate factors important in the determination of life history pattern.

Two co-occurring xanthid crabs, Panopeus herbstii Milne Edwards and Eurypanopeus depressus (Smith), are well suited for investigations of this nature. These broadly distributed, euryhaline crabs live in intertidal oyster reef communities dominated by the oyster Crassostrea virginica Gmelin (Rathbun, 1930; Ryan, 1956; Williams, 1965). They are the most conspicuously mobile members of the reef community at North Inlet, South Carolina and are well adapted for the utilization of its spatial and trophic resources. They use the reef as a refuge from potential predators and from the effects of desiccation at low tide (Grant and McDonald, 1979). At high tide, both crabs utilize a number of reefassociated species as food (Menzel and Nichy, 1958; McDermott, 1960; Bahr, 1974; Seed, 1980; Whetstone and Eversole, 1981).

The oyster reefs in which these 2 crabs co-occur are self-contained and temporally stable (Bahr, 1974). They provide shelter and substrata for as many as 300 
other species (Wells, 1961). Community interaction is heavily influenced by low predator pressure and by the high availability of space and food (Bahr, 1974). Seasonal, daily and tidal fluctuations of various environmental parameters add a high degree of physical complexity (McDonald, 1977). In such a habitat, it is predicted that community members will be r-selected, i.e. have a high rate of growth, small size, short life span, high fecundity, small egg size, and high reproductive effort (MacArthur and Wilson, 1967; Pianka, 1970; Stearns, 1976). With these predictions in mind, the life histories of Panopeus herbstii and Eurypanopeus depressus were examined. Interspecific divergence in life history pattern, its possible cause and its possible adaptive value to a co-occurring, related species pair in the intertidal oyster reef were also considered.

\section{MATERIALS AND METHODS}

A $100 \mathrm{~m}$ horizontal transect was established in February 1976 at Clambank Creek, North Inlet, South Carolina $\left(33^{\circ} 18^{\prime} \mathrm{N}, 79^{\circ} 09^{\prime} \mathrm{W}\right)$ in the portion of the midintertidal zone most densely populated by the oyster Crassostrea virginica. Twelve monthly samples of 6 randomly selected $0.5 \mathrm{~m}^{2}$ quadrats of oysters and mud were excavated, and measurements of temperature (air, water, mud surface, mud subsurface at $10 \mathrm{~cm}$ ) and salinity were made along the transect at low tide. To insure capture of all crabs, samples were sorted on-site in a $100 \mathrm{l}$ container. The living crabs were separated according to species and counted. The mean number of each species obtained from the 6 replicates was extrapolated to a mean number of crabs $\mathrm{m}^{-2}$ month ${ }^{-1}$ and this value served as an index of comparative density.

Maximum carapace width (CW) for each crab, including anterolateral spines, was measured to the nearest $0.1 \mathrm{~mm}$ with vernier calipers. The extent of size overlap between the 2 species was determined by sizefrequency analysis based on the $\mathrm{CW}$ of all animals collected during the study.

Ovigerous females were collected twice monthly, counted, measured and frozen for later examination. In all ovigerous females carrying a newly deposited (i.e. black or purple) egg mass, mean egg diameters were calculated from a measurement of 100 eggs. In these egg masses, single egg weights were extrapolated by drying and weighing 10 sets of 10 eggs each, calculating a mean weight for the 10 sets and dividing that mean by 10 . The total number of eggs carried by several ovigerous females of both species was determined by direct count. Reproductive effort (RE) required for the production of an egg mass was expressed as a percentage of female dry weight.
From the measurements of 40 to 150 individuals per species (depending on season), monthly size-frequency histograms were constructed to provide estimates of recruitment times, growth rates and life spans. To aid in the estimation of life spans, a periodic life history table was constructed for both species from a single replacement sampling of approximately 1.000 individuals per species.

\section{RESULTS}

Salinity and temperatures cycled seasonally (Fig. 1). High salinities generally occurred during the warmer months but were also recorded in April and November when the water temperature was only $14^{\circ}$ to $18^{\circ} \mathrm{C}$. During the rainy season, June and July, salinity was often less than $25 \% \mathrm{~S}$. Highest temperatures were

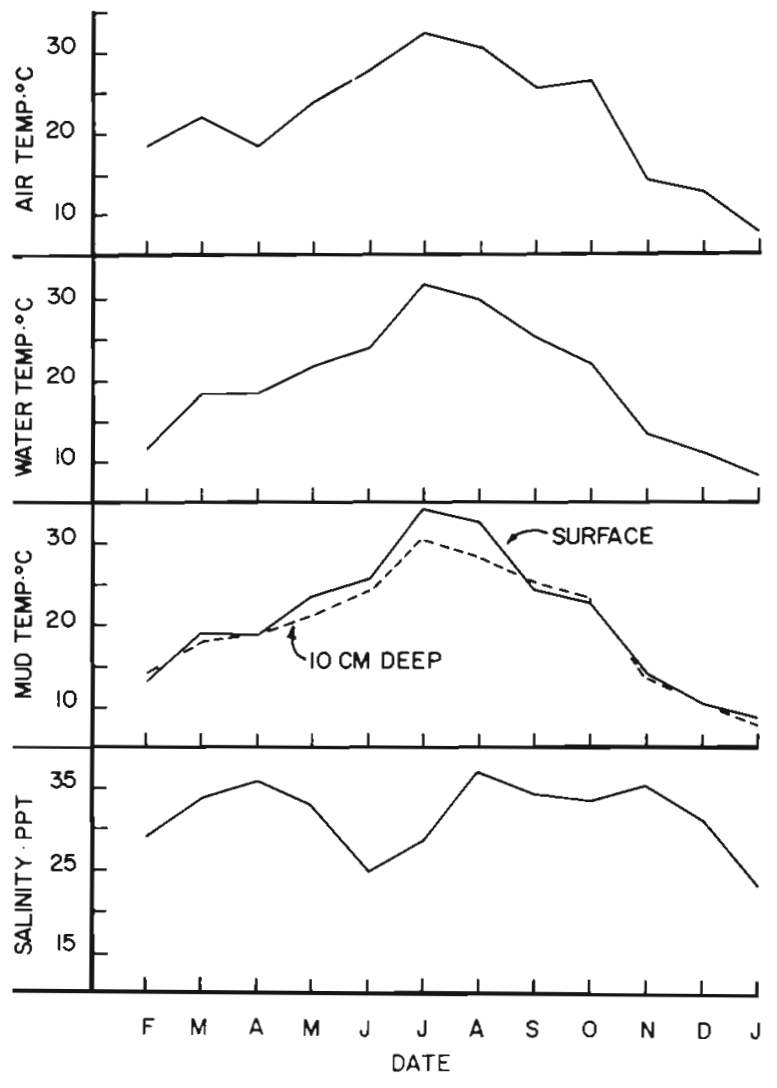

Fig. 1. Clambank Creek, North Inlet, South Carolina. Temperature and salinity from February 1976 to January 1977

recorded during the summer. The mud surface temperature, due to insulation at low tide, was generally the warmest. The 4 temperatures sometimes varied by as much as $10^{\circ} \mathrm{C}$, but thermal gradients were not as sharply defined in the winter.

The comparative densities of both species were not 
significantly different $(p=0.05)$ at any time of the year, although each was highly variable (Fig. 2a). Eurypanopeus depressus became numerically dominant in August and remained so for the duration of the study. The density of Panopeus herbstii steadily declined after a June maximum, while the density of $E$. depressus declined only after September. Both species were least abundant numerically during January, the coldest month.

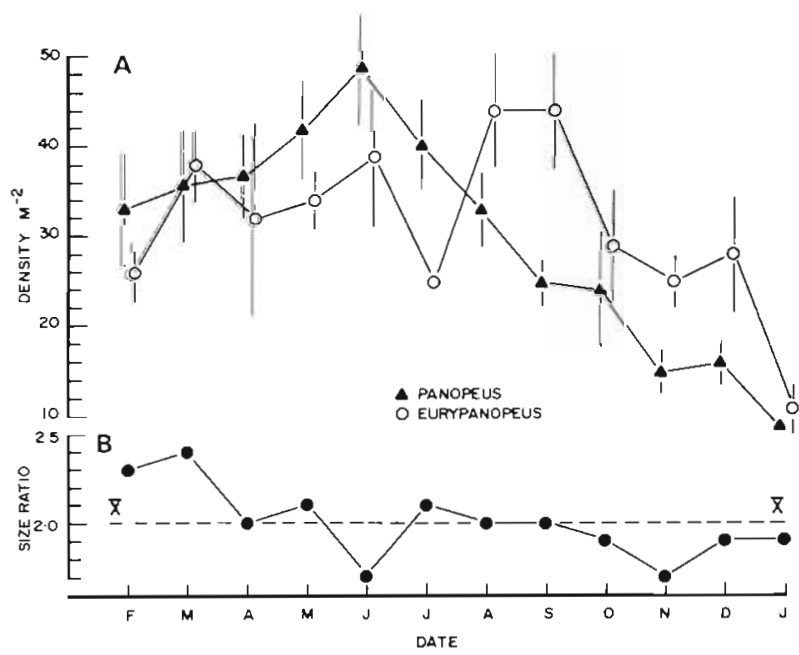

Fig. 2. Panopeus herbstii and Eurypanopeus depressus. (A) Comparative densities, crabs $\mathrm{m}^{-2} \mathrm{mo}^{-1}$. Means \pm 1 standard error. (B) Mean size ratio comparing carapace width of $P$. herbstii to carapace width of $E$. depressus. Horizontal dashed line: mean ratio for the year

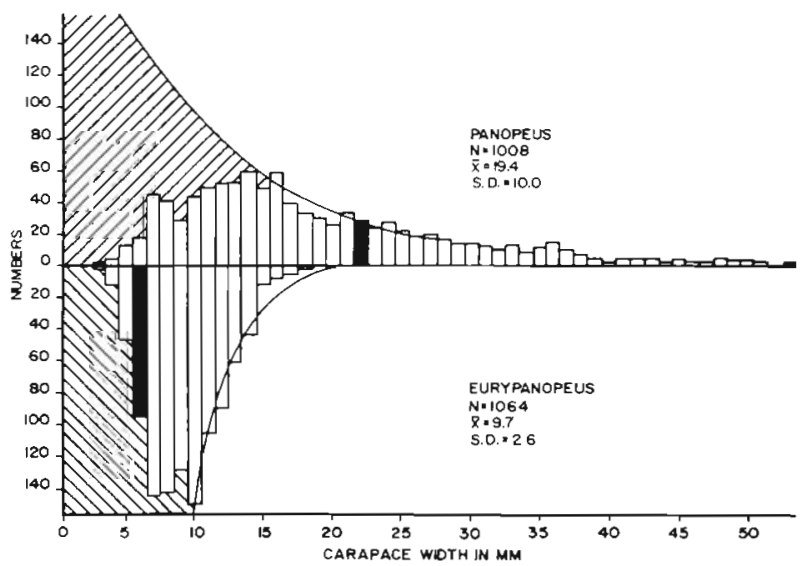

Fig. 3. Panopeus herbstii and Eurypanopeus depressus. Sizefrequency distribution. Zone of diagonal lines: uncollected specimens if Type III survivorship is assumed (Krebs, 1972). Blackened bars are sizes at first reproduction for females

The maximum size ratio (Panopeus herbstii $\mathrm{CW}$ : Eurypanopeus depressus (W) of 2.4:1 occurred in March immediately before the breeding season (Fig. 2b). Minima (1.7:1) occurred in June when recruitment rate was high for small individuals spawned earlier in the season, and November as larger individuals gradually disappeared with the onset of winter.

The total number of individuals of both species collected for the year was similar, but the size distributions of these individuals were quite different (Fig. 3). Panopeus herbstii ranged in size from $4 \mathrm{~mm} \mathrm{CW}$ to

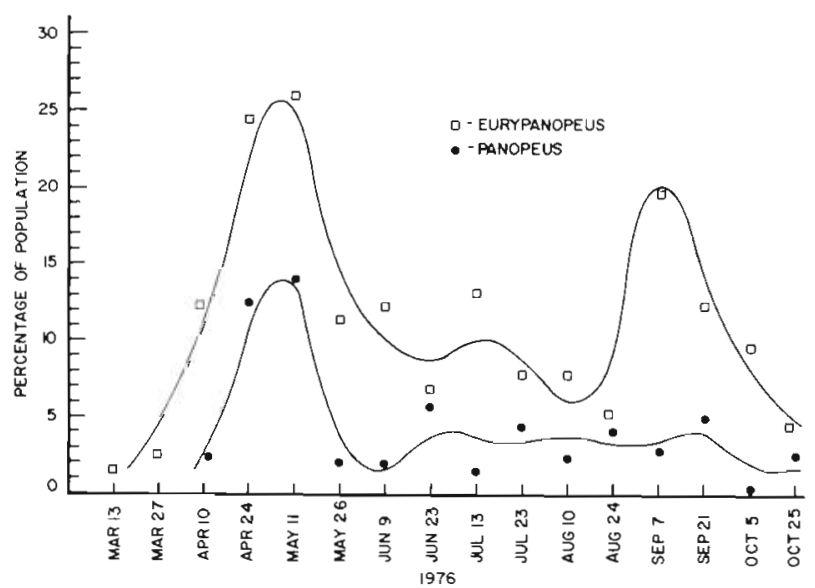

Fig. 4. Panopeus herbstii and Eurypanopeus depressus. Number of ovigerous females expressed as percentage of all females

$55 \mathrm{~mm} \mathrm{CW}(\overline{\mathrm{X}}=19.4 \mathrm{~mm})$ while Eurypanopeus depressus ranged from $4 \mathrm{~mm} \mathrm{CW}$ to $18 \mathrm{~mm} \mathrm{CW}(\overline{\mathrm{X}}=$ $9.7 \mathrm{~mm}$ ). Size overlap between the 2 species occurred primarily between juvenile $P$, herbstii and adult $E$. depressus.

The seasonal breeding periods of the 2 species coincided closely; ovigerous females were found from March through October (Fig. 4). Ovigerous Eurypanopeus depressus outnumbered ovigerous Panopeus herbstii throughout the season and exhibited a bimodal abundance distribution. The distribution of ovigerous $P$. herbstii described a unimodal pattern which peaked along with that of $E$. depressus in late April to nearly May. The water temperature was approximately $15^{\circ} \mathrm{C}$ at the beginning and end of the breeding season.

There was a linear relationship between $\mathrm{CW}$ and the number of eggs per ovigerous female for both species (Fig. 5). The $X$ intercepts of the regression lines indicated that the size at first reproduction was $22 \mathrm{~mm} \mathrm{CW}$ for Panopeus herbstii and $6 \mathrm{~mm} \mathrm{CW}$ for Eurypanopeus depressus. Ovigerous $P$. herbstii ranged in size from $22 \mathrm{~mm} \mathrm{CW}$ to $42 \mathrm{~mm} \mathrm{CW}(\overline{\mathrm{X}}=31.1 \mathrm{~mm} \mathrm{CW})$ and carried from 3,000 to 113,000 eggs (Tab. 1). Ovigerous $E$. depressus ranged in size from $6 \mathrm{~mm} \mathrm{CW}$ to $14 \mathrm{~mm}$ $\mathrm{CW}(\overline{\mathrm{X}}=10.0 \mathrm{~mm} \mathrm{CW})$ and carried from 150 to 4,300 eggs. It was expected that the 3 -fold size difference between the larger $P$. herbstii and the smaller $E$. depressus would be similarly reflected in egg produc- 


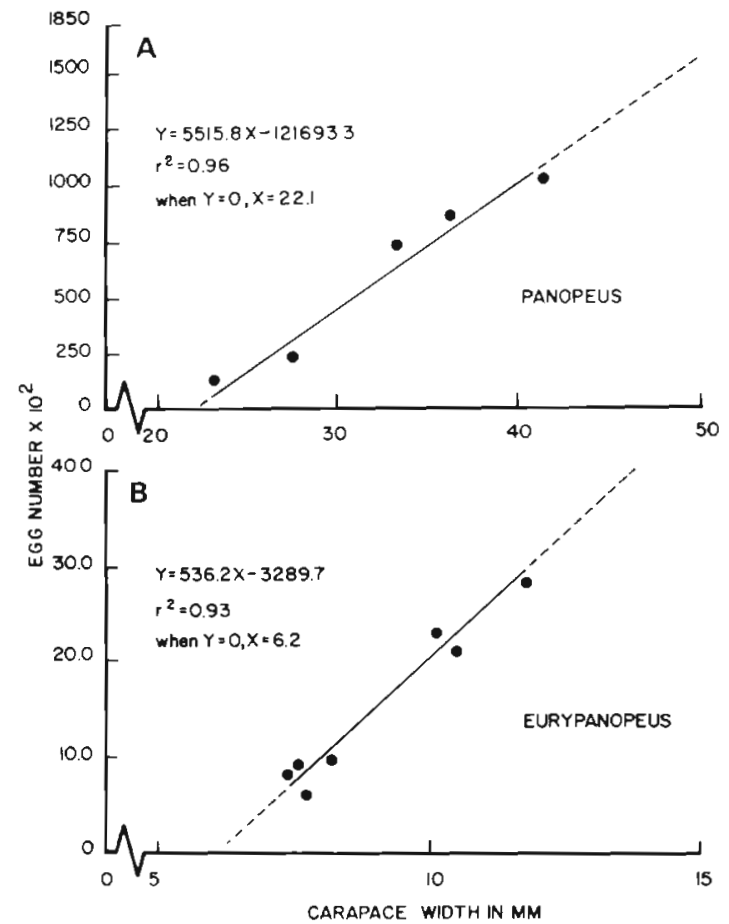

Fig. 5, Panopeus herbstii and Eurypanopeus depressus. Regression of egg number and carapace width of a subsample of ovigerous females. Egg numbers are direct counts

tion. But the egg mass produced by a mean-sized $P$. herbstii was estimated to be 27 times larger than the egg mass produced by a mean-sized $E$. depressus, suggesting a 9-fold difference in fecundity. Total
Table 1. Panopeus herbstii and Eurypanopeus depressus. Estimates of reproductive parameters

\begin{tabular}{|c|c|c|c|}
\hline \multicolumn{2}{|c|}{ Parameter } & \multirow{2}{*}{ P. herbstii } & \multirow{2}{*}{$\frac{\text { E. depressus }}{6.0}$} \\
\hline 1 & $\begin{array}{l}\text { Estimated minimum size } \\
\text { at first reproduction } \\
\text { (Fig. 5) (mm CW) }\end{array}$ & & \\
\hline \multicolumn{4}{|c|}{ Sexually mature females only } \\
\hline 2 & Number & 200 & 535 \\
\hline 3 & Mean CW (mm) & 29.4 & 9.4 \\
\hline 4 & $\mathrm{CW}$ range $(\mathrm{mm})$ & $22.1-45.6$ & $6.2-15.9$ \\
\hline \multicolumn{4}{|c|}{ Ovigerous females only } \\
\hline 5 & Mean egg diameter $(\mathrm{mm})$ & 0.31 & 0.30 \\
\hline 6 & Mean egg dry weight $(\mu g)$ & 5.5 & 4.0 \\
\hline 7 & $\begin{array}{l}\text { Reproductive effort } \\
\text { as a percentage of } \\
\text { female dry weight }\end{array}$ & 8.2 & 7.7 \\
\hline 8 & Number (Fig 4) & 27 & 82 \\
\hline 9 & $\begin{array}{l}\text { Percent of all sexually } \\
\text { mature females }\end{array}$ & 13.5 & 15.3 \\
\hline 10 & Mean CW (mm) & 31.8 & 10.0 \\
\hline 11 & CW range $(\mathrm{mm})$ & $22.6-42.5$ & $6.4-14.2$ \\
\hline & $\begin{array}{l}\text { Mean egg number for } \\
\text { mean CW (Fig. 5) }\end{array}$ & 54,000 & 2,000 \\
\hline 13 & Egg number range & $3,000-113,000$ & $0 \quad 150-4,300$ \\
\hline 14 & $\begin{array}{l}\text { No. of egg masses } / \text { ind }^{-1} \\
\mathrm{y}^{-1} \text { (Fig. } 4 \text { ) }\end{array}$ & 1 & 2 \\
\hline 15 & $\begin{array}{l}\text { Estimated annual egg } \\
\text { production for population } \\
\text { (Parameter } 8 \times 12 \times 14 \text { ) }\end{array}$ & $1,458,000$ & 328,000 \\
\hline
\end{tabular}

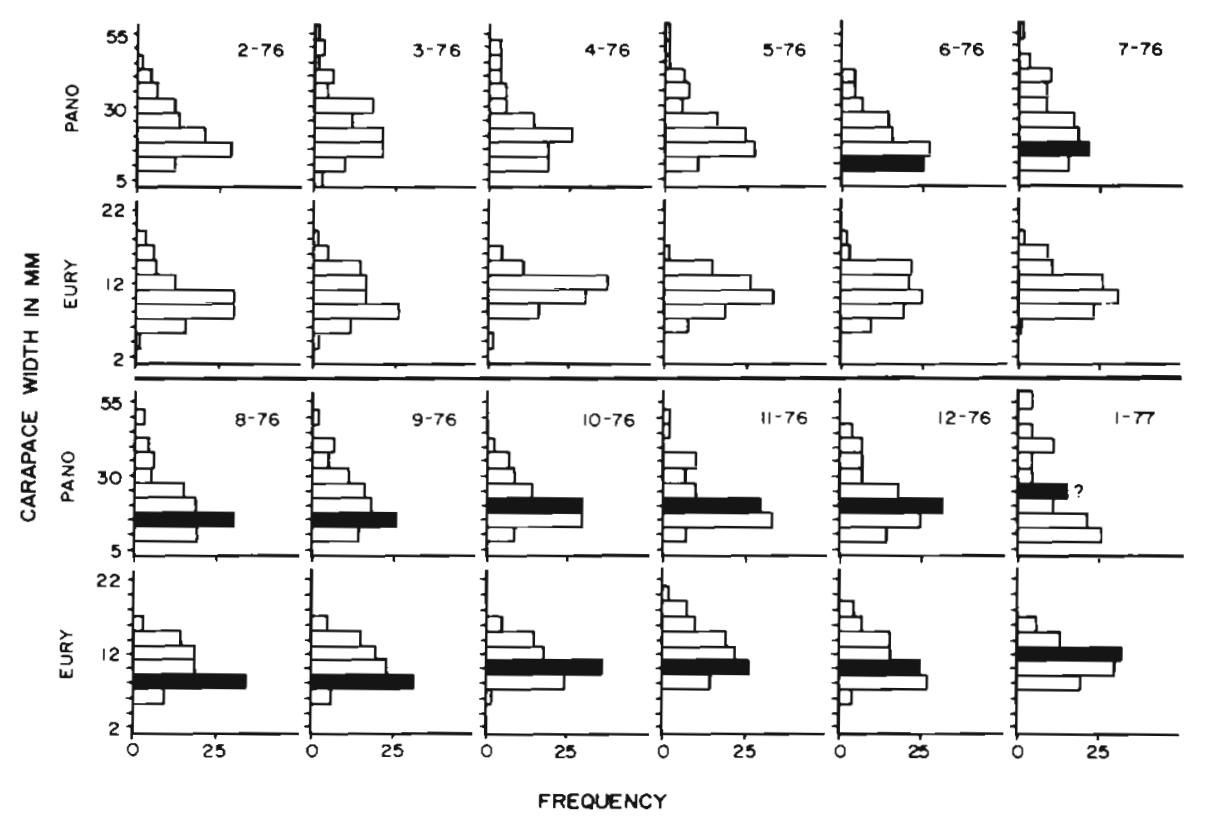

Fig. 6. Panopeus herbstii and Eurypanopeus depressus. Monthly size-frequency distribution. Blackened bars: cohorts followed for growth rate estimates 
annual egg production differed between the 2 species in favor of $P$. herbstii by almost 5-fold, but relative reproductive effort (RE) was almost equal.

Most size classes were present in the sample site throughout the year (Fig. 6). The percentage of small Panopeus herbstii increased in June and January, while the percentage of small Eurypanopeus depressus increased in August and December. The winter increases in small crabs were probably artifacts caused by low sample size. Summer increases, interpreted as true recruitment, appeared 30 to $90 \mathrm{~d}$ after the peak appearance of ovigerous females. Recruitment for both species was gradual and sporadic throughout the summer. Growth rates estimated from Fig. 6 indicate that $P$. herbstii grew from $10 \mathrm{~mm}$ to $20 \mathrm{~mm}$ from June through December, $E$. depressus from $8 \mathrm{~mm}$ to $12 \mathrm{~mm}$ from August through January.
The life table for both species contained 7 size classes (Tab. 2). To estimate the time interval represented by each size class, it was assumed that each was the product of a discrete peak in reproductive activity as evidenced by peaks in the abundance of ovigerous females (Fig. 4). Since ovigerous Panopeus herbstii exhibited 1 peak of abundance during the year and Eurypanopeus depressus exhibited 2, it followed that each size class of $P$. herbstii represented 1.0 yr while each size class of $E$. depressus represented $0.5 \mathrm{yr}$. These time estimates produced tentative and contrasting life histories for both crabs when combined with estimates of size at first reproduction from Fig. 5 and estimates of growth rate from Fig. 6 (Tab. 3). P. herbstii,

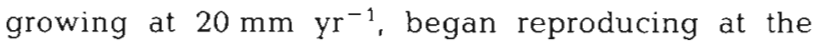
beginning of its second summer (Year 1) and thereafter reproduced annually throughout its maximum esti-

Table 2. Panopeus herbstii (A) and Eurypanopeus depressus (B). Periodic life tables constructed from a single replacement sampling of approximately 1000 individuals per species. $l_{x}$ : number of survivors at start of size class $X_{i} d_{x}$ : number dying during interval $\mathrm{X}$ to $\mathrm{X}+\mathrm{l}_{;} \mathrm{q}_{\mathrm{x}}$ : rate of mortality $\left(\mathrm{d}_{\mathrm{x}}+\mathrm{l}_{\mathrm{x}}\right)$; $\mathrm{L}_{\mathrm{x}}$ : average number alive during interval; $\mathrm{T}_{\mathrm{x}}$ : summation of all $\mathrm{L}_{\mathrm{x}}$; $\mathrm{e}_{\mathrm{x}}$ : mean longevity (in intervals) during interval

\begin{tabular}{|c|c|c|c|c|c|c|}
\hline (A) Size class (X) & $\mathrm{l}_{\mathrm{x}}$ & $d_{x}$ & $\mathrm{q}_{\mathrm{x}}$ & $\mathrm{L}_{\mathrm{x}}$ & $\mathrm{T}_{\mathrm{x}}$ & $e_{x}$ \\
\hline 0 & 965 & 129 & 0.134 & 900.5 & 2285.5 & 2.37 \\
\hline I & 836 & 393 & 0.470 & 639.5 & 1385.0 & 1.65 \\
\hline II & 443 & 172 & 0.338 & 357.0 & 745.5 & 1.68 \\
\hline III & 271 & 118 & 0.435 & 212.0 & 388.5 & 1.43 \\
\hline IV & 153 & 71 & 0.464 & 117.5 & 176.5 & 1.15 \\
\hline V & 82 & 64 & 0.780 & 50.0 & 59.0 & 0.72 \\
\hline VI & 18 & 18 & 1.000 & 9.0 & 9.0 & 0.50 \\
\hline (B) Size class (X) & $1_{x}$ & $d_{x}$ & $q_{x}$ & $\mathrm{~L}_{\mathrm{x}}$ & $\mathrm{T}_{\mathrm{x}}$ & $e_{x}$ \\
\hline 0 & 1001 & 164 & 0.164 & 919.0 & 2202.5 & 2.20 \\
\hline I & 837 & 305 & 0.364 & 684.5 & 1283.5 & 1.53 \\
\hline II & 532 & 272 & 0.511 & 396.0 & 599.0 & 1.13 \\
\hline III & 260 & 215 & 0.827 & 152.5 & 203.0 & 0.78 \\
\hline IV & 45 & 25 & 0.556 & 32.5 & 50.5 & 1.12 \\
\hline $\mathrm{V}$ & 20 & 12 & 0.600 & 14.0 & 18.0 & 0.90 \\
\hline VI & 8 & 8 & 1.000 & 4.0 & 4.0 & 0.50 \\
\hline
\end{tabular}

Table 3. Panopeus herbstii and Eurypanopeus depressus. Major life history parameters assuming constant growth rates and fixed reproductive patterns

\begin{tabular}{|lcc|}
\hline \multicolumn{1}{|c}{ Parameter } & P. herbstii & E. depressus \\
\hline 1 Growth rate $\left(\mathrm{mm} \mathrm{yr}^{-1}\right.$ ) & 20 & 10 \\
2 Size at first reproduction (mm) & 22 & 6 \\
3 Time of first egg mass & at beginning of 2nd summer & at end of 1 st summer \\
4 Generation time (yr) & 1.0 & 0.5 \\
5 Mean expectation of longevity & 2.3 & 2.2 \\
at start of life (intervals) (Tab. 2) & 2.3 & 1.1 \\
6 Mean life span (yr) (Parameter 4 $\times 5)$ & 7 & 7 \\
7 Number of size classes (Tab. 2) & 7.0 & 3.5 \\
8 Maximum life span (yr) (Parameter $4 \times 7)$ & & \\
\hline
\end{tabular}


mated life span of $7.0 \mathrm{yr}$. In contrast, E. depressus grew at a rate of $10 \mathrm{~mm} \mathrm{yr}^{-1}$ and, if spawned during the first peak of reproductive activity (Fig. 4), began reproducing by the end of its first summer (Year 0). Thereafter, reproduction for female $E$. depressus occurred twice annually throughout its maximum estimated life span of $3.5 \mathrm{yr}$. For both species, it was estimated that reproduction began about half-way into the mean life span which, in turn, occupied only $30 \%$ of the estimated maximum.

\section{DISCUSSION}

Panopeus herbstii and Eurypanopeus depressus, while living in the same microhabitat, exhibit life history patterns that are different in many ways and similar in others (Tab. 4). The explanations for divergent life history patterns in co-occurring, related species are usually not very obvious because the causal connection to some physical factor(s) is difficult to demonstrate. Trophic and spatial factors have received much attention as possible explanations. Menge (1975) has shown that Pisaster ochraceous, the larger of 2 co-occurring intertidal sea stars, has a

Table 4. Panopeus herbstii and Eurypanopeus depressus. Comparison of life history patterns

\begin{tabular}{|lll|}
\hline Parameter & P. herbstii & E. depressus \\
\hline Size & larger & smaller \\
Growth rate & higher & lower \\
Life span & longer & shorter \\
Fecundity & greater & lesser \\
Sexual maturity & later & earlier \\
Number of broods per life & less & more \\
Egg diameter & equal & equal \\
Reproductive effort & equal & equal \\
Density & equal & equal \\
\hline
\end{tabular}

higher fecundity, matures at a larger size and has a longer expected life span than the smaller Leptasterias hexactis. He suggests that differences in feeding activity maxima for the adults and differences in food availability patterns for the larvae and released young (trophic differences) account for the difference in adult size.

Apparently the same collection of life history traits is found in the co-occurring prosobranch gastropod pair Thais lamellosa and T. emarginata (Spight, 1979). The larger $T$. lamellosa matures at a larger size, lives longer, is more fecund and spawns less frequently than the smaller $T$. emarginata. Spight (1979), in contrast to Menge (1975), argues that microhabitat differences (spatial factors) account for the observed variations in life history patterns. That is, requirements of different, yet perhaps adjacent, microhabitats cause selection for different life histories. In this case, the smaller $T$. emarginata lived higher on the shore where physical stress apparently selects against the very same collection of life history attributes common to the larger member of a co-occurring, related species pair.

The pattern of variation in life history between Panopeus herbstii and Eurypanopeus depressus is the same as that found for sea stars (Menge, 1975) and for snails (Spight, 1979). This pattern is not totally explained by trophic or spatial factors alone. Long term field observations of $P$. herbstii and $E$. depressus suggest that differences in both trophic habits and microhabitat preferences may be responsible for the observed variation.

Adult Panopeus herbstii are predators of the oyster Crassostrea virginica (Menzel and Nichy, 1958; McDermott, 1960; Bahr, 1974), the hard clam Mercenaria mercenaria (Whetstone and Eversole, 1981), the mussels Modiolus sp. and Brachidontes sp. (Seed, 1980), and the barnacle Balanus sp. (McDermott, 1960; Bahr, 1974). Gut analyses consistently reveal the presence of oyster, clam, mussel and barnacle shell fragments along with partially digested tissue (unpubl. own data). Algae, detritus and crustacean fragments are found to a smaller extent. The smaller Eurypanopeus depressus consumes primarily algae and detritus scraped from the substrate (Bahr, 1974; McDonald, 1977). Bahr (1974) reported that amphipods are a possible prey item. Gut contents include predominantly algae and detritus, some shell fragments, polychaete setae, sponge spicules and pieces of crustacean exoskeleton (unpubl. own data). The greater variety of materials found in the gut compared to $P$. herbstii suggests a more omnivorous diet for $E$. depressus.

There is a large amount of space available in the intertidal oyster reef. Bahr (1974) calculated $50 \mathrm{~m}^{2}$ of total surface area for every $1 \mathrm{~m}^{2}$ of unit area. There are data to suggest that adult Panopeus herbstii and adult Eurypanopeus depressus utilize somewhat different microhabitats within this space. $P$. herbstii is larger than E. depressus (McDonald, 1977; this study). $P$. herbstii is also taller, i.e. it has a larger carapace height to carapace width ratio than $E$. depressus (McDonald, 1977). This difference in size and shape may contribute to selection for different microhabitats. For example, in the field, adult $P$. herbstij are rarely found in the narrow spaces between living oysters, but are more common in the grottoes and depressions of the mud/ oyster reef interface. The smaller, flatter $E$. depressus is rarely found on the mud surface, but generally restricted to the narrow spaces within dead shells and between living oysters (own obs.).

The differences in trophic habit and microhabitat 
preference so far discussed are observed only between adult Panopeus herbstii and adult Eurypanopeus depressus. A slightly different situation exists when juvenile $P$. herbstii and adult $E$. depressus are compared. For the first $25 \%$ of its life span, $P$. herbstil overlaps in size with E. depressus (Fig. 3). During this period, differences in trophic habit and microhabitat preference are not as distinct as those seen in the comparison of adults (McDonald, 1977). Until $P$. herbstii attains a size of approximately $20 \mathrm{~mm} \mathrm{CW}$, its effectiveness as a bivalve predator is extremely limited (Whetstone and Eversole, 1981). Other smaller food items must be utilized, many of which are also food items for E. depressus. Gut analyses indicate major differences in the trophic habits of juvenile and adult p. herbstii (unpubl. own data). Shell fragments are less common and a greater variety of food types are encountered in juveniles. The diets of juvenile $P$. herbstii and adult $E$. depressus are more comparable than those of the adults. In order to share this temporarily more similar trophic habit with adult E. depressus, juvenile $P$. herbstii move into the microhabitat of adult $E$. depressus, i.e. the narrow spaces between living oysters (own unpubl. data).

A combination of trophic and microhabitat factors could explain the co-occurrence of Panopeus herbstii and Eurypanopeus depressus in the intertidal oyster reef, and possibly account for the divergence in life history patterns. Reaka (1979), in a study of 31 populations of stomatopod crustaceans, concluded that differences in body size and the effects of competition on growth explained the variation in life history pattern found within this group. But as shown in this study, life history variation can also be accounted for by differences in trophic habit and microhabit preference. Therefore, the ultimate causal factors responsible for the selection of life history variation remain to be demonstrated.

To determine the origin of and causes for life history variation within brachyurans (or, for that matter, any other taxa), extremely comprehensive life history data are required. Such compilations could serve 2 purposes. Firstly, the family Xanthidae, which includes Panopeus herbstii and Eurypanopeus depressus, is one of the largest brachyuran families (Warner, 1977). Life history information exists for no more than 10 or 12 of the 138 genera comprising the group, representing as few as 15 species. Such information could provide clues to the clarification of relationships within the family which has historically been a taxonomically difficult group and may not represent a natural assemblage (Šteřcić, 1971). Secondly, comprehensive life history data interpreted from a 'tactical' perspective (Stearns, 1976) could help define the prototypic brachyuran life history strategy which is poorly known.
Acknowledgements. This research was supported by a Belle W. Baruch Predoctoral Fellowship in Marine Biology at the University of South Carolina. Financial assistance during the preparation of the manuscript was provided by a Postdoctoral Research Fellowship in Tropical Crustacean Biology from the Smithsonian Institution/Ft. Pierce Bureau. I thank R. Gore, A. Hines, P. Linley, J. McDermott, J. Pilger, S. Stancyk, J. Vernberg and $M$. Wesolowski for encouragement, advice and assistance with earlier drafts. The comments of 3 anonymous reviewers were very helpful. This paper is Contribution No. 440, Belle W Baruch Institute for Marine Biology and Coastal Research, University of South Carolina, Columbia, South Carolina, 29208, USA.

\section{LITERATURE CITED}

Bahr, L. M. (1974). Aspects of the structure and function of the intertidal oyster reef community in Georgia, Ph. D. thesis, University of Georgia

Emmel, T. C. (1976). Population biology. Harper and Row, New York

Grant, J., McDonald, J. (1979). Desiccation tolerance of Eurypanopeus depressus (Smith) (Decapoda: Xanthidae) and the exploitation of microhabitat. Estuaries 2: 172-177

Hutchinson, G. E. (1978). An introduction to population biology. Yale University Press, New Haven, Conn.

Krebs, C. J. (1972). Ecology, the experimental analysis of distribution and abundance. Harper and Row, New York

MacArthur, R., Wilson, E. (1967). The theory of island biogeography. Princeton University Press, Princeton, N.J.

McDermott, J. (1960). The predation of oysters and barnacles by crabs of the family Xanthidae. Proc. Pennsylvania Acad. Sci. 34: 199-211

McDonald, J. (1977). The comparative intertidal ecology and niche relations of the sympatric mud crabs, Panopeus herbstii Milne Edwards and Eurypanopeus depressus (Smith), at North Inlet, South Carolina, USA (Decapoda: Brachyura: Xanthidae), Ph. D. thesis, University of South Carolina

Menge, B. (1975). Brood or broadcast? The adaptive significance of different reproductive strategies in the two intertidal sea stars, Leptasterias hexactis and Pisaster ochraceous. Mar. Biol. 31: 87-100

Menzel, R. W., Nichy, F. E. (1958). Studies of the distribution and feeding habits of some oyster predators in Alligator Harbor, Florida. Bull. mar Sci. 8: 125-145

Pianka, E. (1970). On $\mathrm{r}$ - and K-selection. Am. Nat. 104: 592-597

Rathbun, M. J. (1930). The cancroid crabs of America of the families Euryalidae, Portunidae, Atelecyclidae, Cancridae and Xanthidae. Bull. U.S. Natl. Mus. 152: 1-609

Reaka, M. (1979). The evolutionary ecology of life history patterns in stomatopod Crustacea. In: Stancyk, S. (ed.) Reproductive ecology of marine invertebrates. University of South Carolina Press, Columbia, S.C., pp. 235-260

Ryan, E. (1956). Observations on the life histories and distribution of the Xanthidae of Chesapeake Bay. Am. Midl. Nat. 56: 138-162

Seed, R. (1980). Predator-prey relationships between the mud $\mathrm{crab}$, Panopeus herbstii, the blue crab, Callinectes sapidus and the ribbed mussel, Geukensia (= Modiolus) demissa. Estuar. coast. mar. Sci. 11: 445-458

Spight, T. (1979). Environment and life history. In: Stancyk, S. (ed.) Reproductive ecology of marine invertebrates. University of South Carolina Press, Columbia, S.C., pp. $135-143$ 
Stancyk, S. (Ed.) (1979). Reproductive ecology of marine invertebrates. University of South Carolina Press, Columbia, S.C.

Stearns, S. (1976). Life history tactics: a review of the ideas. Q. Rev. Biol. 51: 3-47

Stearns, S. (1977). The evolution of life history traits: a critique of the theory and a review of the data. Ann. Rev. Ecol. Syst. 8: $145-171$

Stearns, S. (1980). A new view of life history evolution. Oikos 35: $266-281$

Stev̌cić, Z. (1971). The main features of brachyuran evolution. Syst. Zool. 20: $331-340$
Warner, G. F. (1977). The biology of crabs, Elek Science London

Wells, H. (1961). The fauna of oyster beds with special reference to the salinity factor. Ecol. Monogr. 31: 239-266

Whetstone, J., Eversole, A. (1981). Effect of size and temperature on mud crab, Panopeus herbstii, predation on hard clams, Mercenaria mercenaria. Estuaries 4: 153-156

Williams, A. B. (1965). Marine decapod crustaceans of the Carolinas. Fish. Bull. Fish. Wildl. Serv. U.S. 65: 1-298

This paper was presented by Professor J. Lawrence; it was accepted for printing on January 2, 1982 